\title{
The Impact of the SARS-CoV-2 Pandemic in PID Patients Receiving Ig Replacement Therapy
}

\author{
Sukru Cekic $^{1} \cdot$ Fatih Cicek $^{1} \cdot$ Sara Sebnem Kilic ${ }^{1}$ \\ Received: 30 September 2020 / Accepted: 28 December 2020 / Published online: 15 January 2021 \\ (C) The Author(s), under exclusive licence to Springer Science+Business Media, LLC part of Springer Nature 2021
}

\section{Dear Editor}

Severe acute respiratory syndrome coronavirus 2 (SARSCoV-2), a novel coronavirus responsible for coronavirus disease (COVID-19), was first reported in Wuhan-China in December 2019 [1]. The disease's severity ranges from asymptomatic to serious and life-threatening complications such as macrophage activation syndrome, end-organ damage, and acute respiratory distress syndrome (ARDS) [2]. There is limited data on the SARS-CoV-2 pandemic's impact on healthrelated quality of life (HRQOL) among immunocompromised patients. In this study, we aimed to evaluate the effects of the SARS-CoV-2 pandemic on treatment modalities and quality of life in patients with primary immunodeficiencies (PIDs) who received immunoglobulin replacement therapy.

\section{Methods}

\section{Participants}

A total of 71 patients with PID who received immunoglobulin replacement therapy and 31 healthy controls were included in our study. All patients were questioned about their lifestyle and medical conditions, protection measures during the SARS-CoV-2 pandemic, compliance with isolation rules, and changes in the immunoglobulin replacement route

Sara Sebnem Kilic

sebnemk1@uludag.edu.tr

Sukru Cekic

drsukrucekic@gmail.com

Fatih Cicek

drfatihcck@gmail.com

1 Department of Pediatrics, Division of Immunology and Rheumatology, Bursa Uludag University Faculty of Medicine, Bursa, Turkey (intravenously or subcutaneously). While the patients with PID who are older than 12 years and controls answered the questions themselves, PID patients aged between 5 and 12 answered under the supervision of their parents. The questionnaire was answered by the parents of patients under 5 years of age with a diagnosis of PID. The data of patients under 12 years old and have neurological disorders or mental problems were not included in the comparisons.

The female to male ratio of the patients was 0.65 (28/43), and their mean age was $23.5 \pm 19.1$ years $(0.8-70.8)$. Common variable immunodeficiency (CVID) was the most common type of PID subgroup in our cohort $(n=33$, $46.5 \%$ ). The general characteristics of the cases were shown in Table S1. Controls were compatible with the patient group in terms of age and gender.

\section{Questionnaires}

The questionnaire form was created in 3 parts. In the first part, all patients were asked whether they comply with the protection measures against SARS-CoV-2 infection (compliance with general recommendations and practice social distancing, mask-wearing, hand-washing). The second part includes questions about measuring the anxiety level with visual ana$\log$ scales (VAS) (0, not present; 10, very severe) against SARS-CoV-2 infection, and the third part comprises the WHO quality of life questionnaire which was validated in Turkish language [3, 4].

The surveys were conducted within 6 months after SARSCoV-2 was first seen in Turkey.

\section{Statistical Analysis}

Categorical data were expressed as frequencies and percentages and continuous data were reported as means \pm standard deviation (SD) or median (minimum and maximum). Categorical variables were compared by the Pearson chisquare test. Group comparisons were made using the 
Table 1 The anxiety levels of patients measured by VAS (0: not at all, 10: very much)

\begin{tabular}{|c|c|c|c|c|}
\hline & $\begin{array}{l}\text { Gender } \\
\text { Age }\end{array}$ & $\begin{array}{l}\text { Female } \\
(n=22) \\
\text { Mean } \pm \text { SD } \\
\text { Med (min-max) } \\
32.49 \pm 15.06\end{array}$ & $\begin{array}{l}\text { Male } \\
(n=20) \\
\text { Mean } \pm \text { SD } \\
\text { Med (min-max) } \\
37.35 \pm 18.31\end{array}$ & $0.355 \dagger$ \\
\hline 1 & How afraid are you of SARS-CoV-2 infection in general? & $\begin{array}{l}6,20 \pm 3,65 \\
10(2-10)\end{array}$ & $\begin{array}{l}8.05 \pm 2.70 \\
7(0-10)\end{array}$ & $0.058^{\ddagger}$ \\
\hline 2 & Do you believe SARS-CoV-2 will be more easily transmitted to you? & $\begin{array}{l}7.00 \pm 3.06 \\
10(3-10)\end{array}$ & $\begin{array}{l}8.45 \pm 2.26 \\
7(0-10)\end{array}$ & $0.152^{*}$ \\
\hline 3 & Are you afraid of going out? & $\begin{array}{l}6.15 \pm 3.17 \\
8,5(2-10)\end{array}$ & $\begin{array}{l}7.86 \pm 2.62 \\
5(0-10)\end{array}$ & $0.050^{*}$ \\
\hline 4 & $\begin{array}{l}\text { Are you worried about the spread of SARS-CoV-2 infection from market } \\
\text { or market products coming from outside the home? }\end{array}$ & $\begin{array}{l}5.10 \pm 3.26 \\
8(1-10)\end{array}$ & $\begin{array}{l}7.45 \pm 2.48 \\
5(0-10)\end{array}$ & $0.012^{\star}$ \\
\hline 5 & Have your concerns increased about your health? & $\begin{array}{l}5.45 \pm 3.28 \\
8,5(0-10)\end{array}$ & $\begin{array}{l}7.55 \pm 2.94 \\
5(0-10)\end{array}$ & $0.034^{*}$ \\
\hline 6 & Are you afraid of coming to the hospital? & $\begin{array}{l}4.25 \pm 4.14 \\
9.5(0-10)\end{array}$ & $\begin{array}{l}7.86 \pm 3.02 \\
3(0-10)\end{array}$ & $0.008^{*}$ \\
\hline 7 & How sad it is for you not to be able to go outside? & $\begin{array}{l}3.45 \pm 3.59 \\
7.5(0-10)\end{array}$ & $\begin{array}{l}6.73 \pm 3.34 \\
3(0-10)\end{array}$ & 0.004 * \\
\hline 8 & How do you think the SARS-CoV-2 epidemic affected your treatment? & $\begin{array}{l}4.40 \pm 4.08 \\
5(0-10)\end{array}$ & $\begin{array}{l}4.14 \pm 3.69 \\
4.5(0-10)\end{array}$ & $0.826^{\ddagger}$ \\
\hline
\end{tabular}

$\uparrow$ Independent sample $t$ test

* Mann-Whitney $U$ test

$V A S$ visual analog scale, $S D$ standart deviation, Med median, Min minimum, Max maximum

independent sample $t$ test or the Mann-Whitney $U$ test, depending on whether the variables have a normal distribution. Statistical analyses were performed using the statistical package SPSS 23 (IBM corp.). $P$ values less than 0.05 were considered statistically significant.

\section{Results}

The rate of patients who stated that they followed the isolation rules was $94.4 \%(n=67)$. Of the patients, $12.7 \%(n=9)$ reported that they did not go to the hospital for their routine controls to avoid SARS-CoV-2 transmission. Compliance with isolation rules in patients and the changes in their lives during the SARS-CoV-2 pandemic are summarized in Table S2.

Although recommended to all patients who can apply, only 18 out of 65 patients who were previously receiving IVIG shifted to home-based treatment with subcutaneous immunoglobulin (SCIG) administration. Six of the 18 patients who switched to subcutaneous therapy wanted to return to IVIG after a short time to avoid frequent abdominal injection. HRQOL scores were similar in patients using either the subcutaneous or the intravenous routes. In addition, there was no difference between the quality of life and anxiety scores of 12 patients who switched from IVIG to SCIG before and after conversion.
There was no statistically difference between the scores of anxiety and quality of life in patients over the age of 12 receiving IVIG or SCIG. However, among the patients over 12 years of age, changes in sleep patterns $(n=8,53.3 \%)$ were higher in patients receiving SCIG than those receiving IVIG $(n=5,(18.5 \%)(p=0.035)$.

Of the patients diagnosed with PID, $12.7 \%(n=9)$ had a history of contact with a SARS-COV-2 positive individual. Among them, four had unclassified hypogammaglobulinemia, 2 with hypogammaglobulinemia, 1 with ataxia telangiectasia, 1 with nuclear factor kB1 (NFKB1) deficiency, and 1 with $\mathrm{IgG} 2$ deficiency. A swab test was performed in 22 cases diagnosed with PID due to contact or clinical suspicion. The SARS-CoV-2 RT-PCR test was positive in 2 of the cases tested. Among these patients, the patient with unclassified hypogammaglobulinemia treated with IVIG was asymptomatic, while the patient with CVID treated with SCIG had mild complaints (mild cough and sore throat).

Changes in appetite $(n=8,61.5 \%)$ were significantly higher in patients with changes in sleep patterns than those without $(n=4,13.8 \%)(p=0.003)$. In addition, the severity of sadness due to inability to go out $(7 \pm 3.58)$ and the level of anxiety about health conditions $(8.31 \pm 2.21)$ were higher in patients who stated a change in their sleep patterns compared to patients who did not $(5.76 \pm 3.36 ; 4,34 \pm 3.66)(p=0.035$ and $p=0.037)$. 
Table 2 Anxiety levels and quality of life scores of patients and controls over the age of 12 during the SARS-CoV-2 pandemic

\begin{tabular}{|c|c|c|c|c|}
\hline & & Patients $(n=42)$ & Control $(n=31)$ & \\
\hline \multicolumn{2}{|c|}{ Age (median, minimum, maximum) } & $35.03 \pm 16.81$ & $31.23 \pm 13.06$ & $0.298^{\dagger}$ \\
\hline \multicolumn{2}{|c|}{ Gender $(\mathrm{F} / \mathrm{M})$} & $22 / 20$ & $19 / 12$ & $0.387^{\mathrm{I}}$ \\
\hline \multicolumn{2}{|r|}{ The anxiety levels of patients measured by VAS ( 0 : not at all, 10 : very much) } & $\begin{array}{l}\text { Mean } \pm \text { SD } \\
\text { Med (min-max) }\end{array}$ & $\begin{array}{l}\text { Mean } \pm \text { SD } \\
\text { Med (min-max) }\end{array}$ & $\mathrm{p}$ \\
\hline 1 & How afraid you are of SARS-CoV-2 infection in general? & $\begin{array}{l}7.17 \pm 3.3 \\
8(0-10)\end{array}$ & $\begin{array}{l}6.65 \pm 2.33 \\
7(0-10)\end{array}$ & $0.115^{+}$ \\
\hline 2 & Do you believe SARS-CoV-2 infection will be more easily transmitted to you? & $\begin{array}{l}7.76 \pm 2.74 \\
9(0-10)\end{array}$ & $\begin{array}{l}5.90 \pm 2.09 \\
6(2-9)\end{array}$ & $0.01^{*}$ \\
\hline 3 & Are you afraid of going out? & $\begin{array}{l}7.05 \pm 2.99 \\
8(0-10)\end{array}$ & $\begin{array}{l}4.84 \pm 3.60 \\
5(0-10)\end{array}$ & $0.08^{*}$ \\
\hline 4 & $\begin{array}{l}\text { Are you worried about the spread of SARS-CoV-2 infection from market products } \\
\text { coming from outside the home? }\end{array}$ & $\begin{array}{l}6.33 \pm 3.08 \\
7(0-10)\end{array}$ & $\begin{array}{l}5.87 \pm 3.06 \\
6(0-10)\end{array}$ & $0.550^{+}$ \\
\hline 5 & Have your concerns increased about your health? & $\begin{array}{l}6.55 \pm 3.25 \\
7.5(0-10)\end{array}$ & $\begin{array}{l}5.55 \pm 3.37 \\
6(0-10)\end{array}$ & $0.166^{\ddagger}$ \\
\hline 6 & Are you afraid of coming to the hospital? & $\begin{array}{l}6.14 \pm 4 \\
7.5(0-10)\end{array}$ & $\begin{array}{l}6.06 \pm 3.67 \\
7(0-10)\end{array}$ & $0.636^{+}$ \\
\hline 7 & How sad is it for you not to go out? & $\begin{array}{l}5.17 \pm 3.8 \\
5(0-10)\end{array}$ & $\begin{array}{l}4.45 \pm 3.98 \\
5(0-10)\end{array}$ & $0.440^{+}$ \\
\hline 8 & How do you think the SARS-CoV-2 infection epidemic affected your treatment? & $\begin{array}{l}4.26 \pm 3.84 \\
5(0-10)\end{array}$ & $\begin{array}{l}1.10 \pm 2.64 \\
0(0-10)\end{array}$ & - \\
\hline \multicolumn{5}{|c|}{ The EUROHIS-QOL 8-Item (very bad:1, very good:5) } \\
\hline 1 & How would you rate your quality of life? & $\begin{array}{l}3.74 \pm 0.86 \\
4(2-5)\end{array}$ & $\begin{array}{l}3.55 \pm 0.62 \\
4(2-4)\end{array}$ & $0.341^{\ddagger}$ \\
\hline 2 & How satisfied are you with your health? & $\begin{array}{l}3.48 \pm 0.71 \\
4(2-5)\end{array}$ & $\begin{array}{l}3.94 \pm 0.73 \\
4(2-5)\end{array}$ & $0.010^{+}$ \\
\hline 3 & Do you have enough energy for everyday life? & $\begin{array}{l}3.69 \pm 0.98 \\
4(2-5)\end{array}$ & $\begin{array}{l}4.16 \pm 0.69 \\
4(3-5)\end{array}$ & $0.037^{\ddagger}$ \\
\hline 4 & How satisfied are you with your ability to perform your daily living activities? & $\begin{array}{l}3.62 \pm 1.08 \\
4(1-5)\end{array}$ & $\begin{array}{l}4.10 \pm 0.65 \\
4(3-5)\end{array}$ & 0.062 \\
\hline 5 & How satisfied are you with yourself? & $\begin{array}{l}3.98 \pm 0.92 \\
4(1-5)\end{array}$ & $\begin{array}{l}4.19 \pm 0.65 \\
4(3-5)\end{array}$ & 0.398 \\
\hline 6 & How satisfied are you with your personal relationships? & $\begin{array}{l}4.02 \pm 1.1 \\
4(1-5)\end{array}$ & $\begin{array}{l}3.58 \pm 1.03 \\
4(1-5)\end{array}$ & $0.031^{*}$ \\
\hline 7 & Have you got enough money to meet your needs? & $\begin{array}{l}3.95 \pm 1.08 \\
4(1-5)\end{array}$ & $\begin{array}{l}3.68 \pm 0.75 \\
4(3-5)\end{array}$ & $0.091^{1}$ \\
\hline \multirow[t]{2}{*}{8} & How satisfied are you with the conditions of your living place? & $\begin{array}{l}4.29 \pm 0.86 \\
5(2-5)\end{array}$ & $\begin{array}{l}4.0 \pm 0.82 \\
4(3-5)\end{array}$ & $0.116^{+}$ \\
\hline & QOL total score & $\begin{array}{l}30.76 \pm 4.43 \\
32(21-38)\end{array}$ & $\begin{array}{l}31.19 \pm 4.01 \\
32(22-38)\end{array}$ & $0.771^{t}$ \\
\hline
\end{tabular}

$\dagger$ Independent sample $t$ test

II Chi-square test

† Mann-Whitney $U$ test

$V A S$ visual analog scale, $S D$ standart deviation, Med median, Min minimum, Max maximum, $Q O L$ quality of Life

Most of the patients $(62.9 \%, n=44)$ stated that SARSCoV-2 infection would never end.

The anxiety levels of female patients were higher than men at many points in the survey (Table 1).

The median daily handwashing frequency increased from 6 $(0-20)$ before the pandemic to $10(2-30)$ during the pandemic period in patients with PID $(p<0.001)$. Similar increase was also observed in controls (from 7.5 (3-16) to 15 (2-25) $(p<0.001)$. Hand washing frequency was similar in patient and control groups.

The rates of physical distancing and mask usage were similar in patients and controls. Anxiety levels about the risk of SARS Cov-2 transmission was significantly higher in patients than controls $(p=0.002)$. There was no difference between the 
patient group and the control group in terms of total quality of life scores. However, there was a significant difference between the patient and the control groups in questions number 2 and 6 of the quality of life questionnaire. The level of healthrelated satisfaction in PID patients was found to be lower than the controls $(p=0.01)$. However, their scores in terms of personal relationships were higher than controls $(p=0.031)$ (Table 2).

\section{Discussion}

There are many studies conducted in various specific populations that have shown that the SARS-CoV-2 outbreak negatively affects the quality of life of patients with chronic diseases $[5,6]$. The only study on the quality of life in patients with PID during the SARS-CoV-2 pandemic has been conducted by Pulvirenti et al. recently [7]. They have shown a decrease in HRQOL in patients with CVID who living in an area with high prevalence of SARS-CoV-2 infection in Italy [7]. In our study, while the total quality of life scores in patients with PID were similar to the control group, the satisfaction with their health status was significantly lower in the patients.

Although the level of concern during the SARS-CoV-2 pandemic which measured by VAS was generally high, the quality of life scores was at an acceptable level in our patients. Particularly, female patients were more worried than males, such as fear of getting sick and infecting relatives, a fear of leaving the house, or getting infected in markets and public places. These results suggested that female patients with PID are more prone to anxiety disorders than males during the SARS-CoV-2 pandemic.

It is expected that patients with PID have a high susceptibility to viral infections; on the contrary, the frequency of SARS-CoV-2 infection has not been increased in these patients so far. Meyt et al. reported that the mortality rate due to SARS-CoV 2 infection was $9.6 \%$ in patients with PID. They have been determined that the risk factors for severe SARS-CoV-2 infection in the general population are also valid for patients with PID. However, SARS-CoV-2 infection was more frequent and severe in younger PID patients compared to the general population [8]. Quinti et al. reported that 5 patients with CVID and 2 patients with agammaglobulinemia developed SARS-Cov-2 infection and all patients recovered except the 59-year-old patient with CVID who died due to lung involvement [9]. It was previously reported that two patients with $\mathrm{X}$-linked agammaglobulinemia and a patient with CVID who suffered from SARS-CoV-2 infection recovered successfully $[10,11]$. All three patients had an optimal trough level of IgG at the time of diagnosis and received additional IVIG during their stay in hospital $[10,11]$. Despite living in a risky cosmopolitan city, none of our patients developed SARS-CoV2 infection.

During the SARS-CoV-2 pandemic, many of our patients suffered from changes in sleep patterns and appetite. We thought, since the anxiety threshold may be lower in patients who switched their treatment from IVIg to subcutan, that they may face more changes in appetite. This study has some limitations: which are the quality of life scale of patients and controls was not measured before the SARS-Cov2 pandemic, having a small group of patients, being a single-center study, having a heterogeneous group of patients in terms of diagnosis and age, and many confounding factors that may affect the quality of life which could not be excluded.

In conclusion, it has been found that compliance with the protection measures against SARS-CoV-2 infection was high in PID patients receiving Ig replacement therapy. Despite growing health concerns, their quality of life remained similar to those of the healthy controls. Patients with PID, particularly female patients, have increased concern about SARS-CoV-2 infection. They should be monitored for anxiety disorders during the pandemic.

Supplementary Information The online version contains supplementary material available at https://doi.org/10.1007/s10875-020-00958-5.

Authors' Contributions All authors contributed to the study conception and design. Material preparation, data collection, and analysis were performed by SC, FC, and SSK. The first draft of the manuscript was written by SC and SSK, and all authors commented on previous versions of the manuscript. All authors read and approved the final manuscript.

Data Availability The data that support the study findings are available from the corresponding author upon reasonable request.

\section{Compliance with Ethical Standards}

Conflict of Interest The authors declare that they have no conflict of interest.

Ethical Approval Ethical approval was obtained from Uludag University Faculty of Medicine Medical Research Ethics Committee for the study $(2020-11 / 24)$.

Consent to Publish Participants gave the permission to publish their data.

Consent to Participate The informed consent form was obtained from participants.

\section{References}

1. Harapan H, Itoh N, Yufika A. Coronavirus disease 2019 (COVID19): A literature review. J Infect Public Health. 2020;13(5):667-73.

2. Sohrabi C, Alsafi Z, O'Neill N. World Health Organization declares global emergency: a review of the 2019 novel coronavirus (COVID-19). Int J Surg. 2020;76:71-6. 
3. Schmidt S, Muhlan H, Power M. The EUROHIS-QOL 8-item index: psychometric results of a cross-cultural field study. Eur J Pub Health. 2006;16(4):420-8.

4. Eser E, Lağarlı T, Baydur H, Akkurt V, Akkuș H, Arslan E, et al. EUROHIS (WHOQOL-8.Tr) Türkçe sürümünün Türk toplumundaki psikometrik özellikleri. Turk. J Public Health. 2010;8(3):136-52.

5. Frey MK, Ellis AE, Zeligs K, Chapman-Davis E, Thomas C, Christos PJ, et al. Impact of the COVID-19 pandemic on quality of life for women with ovarian cancer. Am J Obstet Gynecol. 2020. https://doi.org/10.1016/j.ajog.2020.06.049.

6. Liu CH, Stevens C, Conrad RC, Hahm HC. Evidence for elevated psychiatric distress, poor sleep, and quality of life concerns during the COVID-19 pandemic among U.S. young adults with suspected and reported psychiatric diagnoses. Psychiatry Res. 2020. https:// doi.org/10.1016/j.psychres.2020.113345.

7. Pulvirenti F, Cinetto F, Milito C, Bonanni L, Pesce AM, Leodori G, et al. Health-related quality of life in common variable immunodeficiency Italian patients switched to remote assistance during the COVID-19 pandemic. J Allergy Clin Immunol Pract. 2020;8(6): 1894-9.e2.
8. Meyts I, Bucciol G, Quinti I, Neven B, Fischer A, Seoane E, et al. Coronavirus Disease 2019 in patients with inborn errors of immunity: an international study. J Allergy Clin Immunol. 2020:S00916749(20)31320-8.

9. Quinti I, Lougaris V, Milito C, Cinetto F, Pecoraro A, Mezzaroma I, et al. A possible role for B cells in COVID-19? Lesson from patients with agammaglobulinemia. J Allergy Clin Immunol. $2020 \mathrm{Jul} ; 146(1): 211-213 . e 4$. https://doi.org/10.1016/j.jaci.2020. 04.013.

10. Soresina A, Moratto D, Chiarini M, Paolillo C, Baresi G, Focà E, et al. Two X-linked agammaglobulinemia patients develop pneumonia as COVID-19 manifestation but recover. Pediatr Allergy Immunol. 2020. https://publons.com/publon/10.1111/pai.13263.

11. Fill L, Hadney L, Graven K, Persaud R, Hostoffer R. The clinical observation of a patient with common variable immunodeficiency diagnosed as having coronavirus disease 2019. Ann Allergy Asthma Immunol. 2020;125(1):112-4.

Publisher's Note Springer Nature remains neutral with regard to jurisdictional claims in published maps and institutional affiliations. 